\title{
Course Pattern of the Muscular Branch of the Median Nerve in Sri Lankans Hand
}

\author{
Curso del Patrón del Ramo Muscular del Nervio Mediano de la Mano en Sri Lankenses
}

"Kithsiri J. Senanayake; " Sujatha Salgado \& ${ }^{* * * *}$ Ranil Fernando

SENANAYAKE, K. J.; SALGADO, S. \& FERNANDO, R. Course pattern of the muscular branch of the median nerve in Sri Lankans hand. Int. J. Morphol., 27(4):1059-1061, 2009.

SUMMARY: Transligamentous variant of the recurrent motor branch is having a higher risk of getting damage during both endoscopic and open carpal tunnel releases. The incidence of the transligamentous variant is about $7 \%$ to $80 \%$ world wide. This wide variation of the incidence could be due to the failure of identification of the distal edge of the flexor retinaculum from the obliquely oriented fascia that runs from the distal edge. We used two criteria to identify the distal edge; the abrupt change in the thickness of the flexor retinaculum and its colour change in cross section. The incidence of transligamentous variant is rare and the reported high incidence could be due to an error in identification of the distal edge of the flexor retinaculum as shown by Kosin (1998).

KEY WORDS: Median nerve; Muscular branch; Flexor retinaculum; Hand; Sri Lankans.

\section{INTRODUCTION}

Surgical decompression of the carpal tunnel requires special caution regarding the anatomic variations of the recurrent motor branch of median nerve (RMB). It supplies the thenar group of muscles (Sinnatamby, 2001). Any damage to the RMB results in wasting of thenar muscles with loss of opponence (Raftery, 2000). The loss of opponence is a major handicap especially in dominant hand since it impairs the firm palmer grip (Friedman, 1997). Therefore, the identification and preservation of RMB is of paramount importance during a carpal tunnel decompression.

Many anatomic variations of the recurrent motor branch are described in the literature (Friedman). Variations of the number, such as duplications or triplications (Lanz, 1977; Amadio, 1988; Kozin, 1998) and the variations of origin of the RMB, such as arising from the volar aspect of the median nerve (Friedman), originating distal to the flexor retinaculum (Friedman; Kozin; Skandalakis et al., 1992), originates under the flexor retinaculum (Friedman; Skandalakis et al.) and an accessory branch that arises from the median nerve and joining with the recurrent motor branch etc. (Ogden, 1972). Presence of a separate tunnel in flexor retinaculum for recurrent motor branch is another variant (Johnson \& Shrewsbury, 1970).

The transligamentous variant that pierces the flexor retinaculum is considered as a 'high risk' variant due to the fact that it can get inadvertently damaged during the resection of the retinaculum in both open and endoscopic carpal tunnel releases (Skandalakis et al.; Sivarhus et al., 1989). The isolated entrapment of recurrent motor branch is reported in several articles (Sivarhus et al.; Alizadeh et al., 2006). The transligamentous variant could be the culprit of these occasions. Variability in the literature on the anatomy of recurrent branch can be accounted for by failure to properly identify the flexor retinaculum as being separated from the obliquely oriented fascia distal to the flexor retinaculum through which the nerve frequently penetrates (Kozin). Therefore, the incidence of this 'high risk' variant is controversial. In this study we identified the true distal edge of the flexor retinaculum from the obliquely oriented fascia by the abrupt change in the thickness of the fascia overlying the carpal tunnel and the colour of the retinaculum in cross section of the formalin fixed cadavers and attempt to find

\footnotetext{
* Department of Surgery, Rajarata University of Sri Lanka.

** Department of Anatomy, Faculty of Medicine, University of Kelaniya, Sri Lanka.

*** Department of Surgery, Faculty of Medicine University of Kelaniya, Sri Lanka.
} 
the incidences of surgically important variations among Sri Lankans.

\section{MATERIAL AND METHOD}

Sixty hands of both sides were dissected meticulously using a hand lens (15 males, 15 females, age ranging from 30 to 87 years). Cadavers with scars over the carpal tunnel and hand and wrist deformities were excluded. Skin flap is removed over the carpal tunnel and the thenar group of muscles. The tendon of the palmaris longus removed carefully. The recurrent motor branch is identified and traced in a retrograde manner up to the point where it pierces the roof of the carpal tunnel. There after the flexor retinaculum is divided with a 22 gaged scalpel. The point where the abrupt change in the thickness and the colour of the flexor retinaculum in cross section are used to identify the distal edge of the retinaculum from the obliquely oriented fascia. Recurrent branch of the median nerve classified according to the classification proposed by the Skandilakis et al. The extraligamentous variant originates distal to the distal edge of flexor retinaculum and the subligamentous variant originates underneath the flexor retinaculum. The transligamentous variant pierces the retinaculum.

\section{RESULTS}

Extraligamentous variant found in 53 hands (88\%) (Fig. 3) and the subligamentous variant found in 7 hands (12\%) (Fig. 2). No specimen had transligamentous variant.

\section{DISCUSSION}

The incidence of transligamentous variant is $7 \%$ to $80 \%$ world wide (Friedman; Kozin; Skandalakis et al.; Sivarhus et al.; Falconer \& Spinner, 1985). This wide variation of the incidence could be due to the failure of

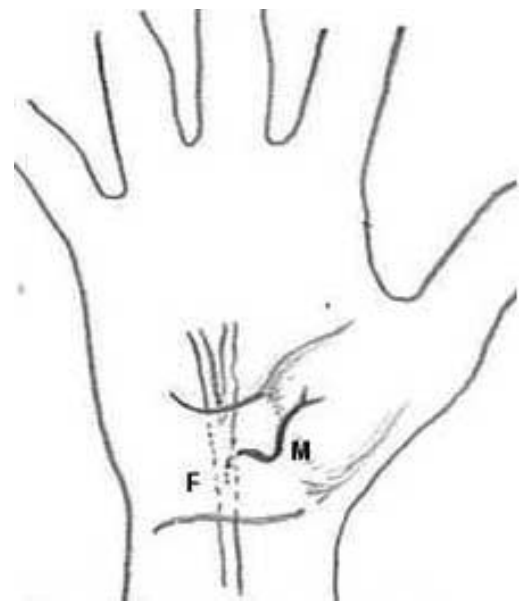

Fig. 1. The transligamentous varient. F. Flexor retinaculum; M. Motor branch.

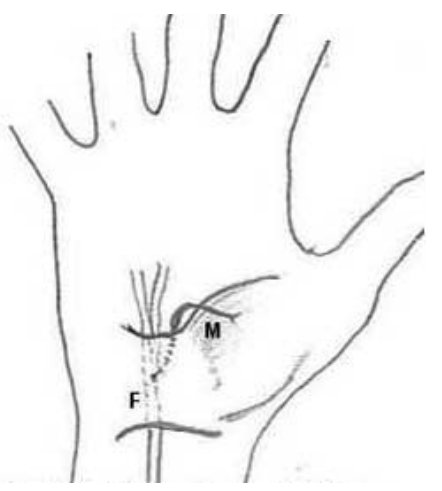

Fig. 2. The subligamentous varient. F. Flexor retinaculum; M. Motor branch.

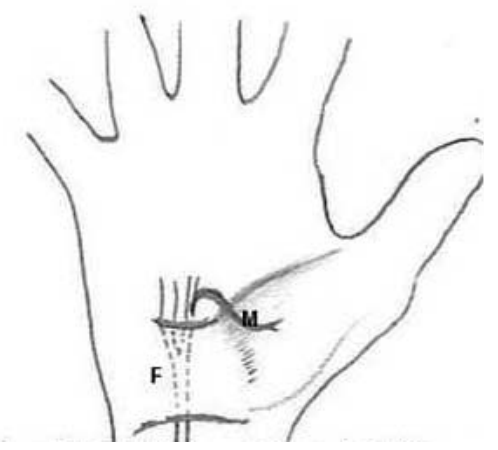

Fig. 3. The extraligamentous varient. F. Flexor retinaculum; M. Motor branch.

Table I. Comparison of the incidences of common variations of recurrent motor branch.

\begin{tabular}{lcccc}
\hline & $\begin{array}{c}\text { Current study } \\
\mathrm{n}=60\end{array}$ & $\begin{array}{c}\text { Alizadeh } \text { et } \text { al. } \\
\mathrm{n}=60\end{array}$ & $\begin{array}{c}\text { Kozin } \\
\mathrm{n}=101\end{array}$ & $\begin{array}{c}\text { Lanz } \\
\mathrm{n}=246\end{array}$ \\
\hline Extraligamentous & $88 \%$ & $46.7 \%$ & $19 \%$ & $46 \%$ \\
Transligamentous & - & $11.7 \%$ & $7 \%$ & $23 \%$ \\
Transfascial & - & $13.3 \%$ & $74 \%$ & - \\
Subligamentous & $12 \%$ & $28.3 \%$ & - & $31 \%$ \\
\hline
\end{tabular}


identification of the distal edge of the flexor retinaculum from the obliquely oriented fascia that runs from the distal edge. The nerves that pierce the obliquely running fascia may be considered as transligamentous variant (Kozin). Therefore a higher number of this variant has been reported. However in cross section of the flexor retinaculum, there is an abrupt change in the thickness at its distal border. We used this criterion together with 'amber colour' of the cross section of the retinaculum of formalin fixed cadavers to identify the distal edge accurately. In our cohort of samples, the extraligamentous variant (Fig. 1) is the commonest followed by the subligamentous variant (Fig. 2). The Table I summarises the incidences of the variations of the RMB in
Alizadeh et al., Lanz, Kozin and the current study. Extraligamentous variant is the commonest variant in most of the studies (Lanz; Kozin; Alizadeh et al.; Olave et al., 1996). Our results tally with Kozin, and this supports the fact that high incidence of transligamentous variant in literature is due inaccurate identification of the distal edge of the flexor retinaculum.

Incidence of transligamentous variant is rare. The reported high incidence could be due to an error in identifying the distal edge as shown by Kozin. However, the potential existence of this variant should be born in mind in both open and endoscopic carpal tunnel release.

SENANAYAKE, K. J.; SALGADO, S. \& FERNANDO, R. Curso del patrón del ramo muscular del nervio mediano de la mano en Sri Lankenses. Int. J. Morphol., 27(4):1059-1061, 2009.

RESUMEN: Las variantes transligamentosas del ramo motor recurrente tienen un mayor riesgo de recibir daños durante la endoscopía y liberación abierta del túnel carpiano. La incidencia de la variante transligamentosa es de, aproximadamente, 7 a $80 \%$ en todo el mundo. Esta amplia variación de la incidencia podría deberse a la falla en la identificación del borde distal del retináculo flexor de la fascia de orientación oblicua que va desde el borde distal. Hemos utilizado dos criterios para identificar el borde distal, el brusco cambio en el grosor del retináculo flexor y su cambio de color en la sección transversal. La incidencia de la variante transligamentosa fue rara y el informe de la alta incidencia podría deberse a un error en la identificación del borde distal del retináculo flexor, como lo demuestra Kosin (1998).

\section{PALABRAS CLAVE: Nervio mediano; Ramo muscular; Retináculo flexor; Mano; Sri Lanka.}

\section{REFERENCES}

Alizadeh, K.; Lahiji, F. \& Phalsaphy, M. Anatomic variations of the median nerve at the carpal tunnel: A cadaver study. Rev. Bras. Ortop., 41(3):83-6, 2006.

Amadio, P. C. Anatomic variations of the median nerve within the carpal tunnel. Clin. Anat., 1:23-31, 1988.

Falconer, D. \& Spinner, M. Anatomic variations in the motor and sensory supply of the thumb. Clin. Orthop. Relat. Res., 195:8396, 1985

Friedman, A. H. Surgical anatomy of the carpal tunnel. Neurosurg. Focus, 3(1):e1, 1997.

Johnson, R. K. \& Shrewsbury, M. M. Anatomical course of the thenar branch of the median nerve-usually in a separate tunnel through the transverse carpal ligament. J. Bone Joint Surg. Am., 52(2):269-73, 1970.

Kozin, S. H. An unusual branch of the median nerve. J. Hand Surg. [Am], 23(5):852-8, 1998.

Lanz, U. Anatomical variations of the median nerve in the carpal tunnel. J. Hand Surg. [Am], 2:44-53, 1977.

Ogden, J. A. An unusual branch of the median nerve. J. Bone Joint Surg. [Am], 54:1779-81,1972.
Olave, E.; Prates, J. C.; Gabrielli, C. \& Pardi, P. Morphometric studies of the muscular branch of median nerve. J. Anat., 189:445-9, 1996.

Raftery, A. T. Locomotor system, applied basic science for basic surgical training. $1^{\text {st }}$ Edition. Edinburgh, Churchill Livingstone, 2000. pp.336-7.

Sinnatamby, C. S. Upper Limb. Last's Anatomy. $10^{\text {th }}$ ed. London, Churchill Livingstone, 2001. pp. 80

Sivarhus, S. W.; Kremachek, T. E.; Smith, W. R.; Busch, T. M. \& Drake, R. C. A cadaveric study of the anatomic variations of the recurrent motor branch of median nerve. Orthop. Rev., 18(3):315-20, 1989.

Skandalakis, J. E.; Colborn, G. L.; Skandalakis, P. N.; McCollam, S. M. \& Skandalakis, L. J. The carpal tunnel syndrome. Part III. Am. Surg., 58(3):158-66, 1992.

Correspondence to:

Dr. Kithsiri J. Senanayake

Lecturer, Department of Surgery

Rajarata University

Received: 23-03-2009

Sri Lanka

Accepted: 21-08-2009

Email: kithsirijanakantha@gmail.com 
